\title{
A Fatal Defect of Interim Administration? Case Application: Kosovo
}

\author{
Peter Ondrovič ${ }^{1}$
}

\begin{abstract}
Some studies have suggested that the interim administration (IA) mission in Kosovo (UNMIK) bas failed in its aim to transform the society and contributed to a complicated completion of the mission. In this article, primarily reports of the UN General-Secretary (SG) on UNMIK are analyzed to answer the question posed in the title. Important development points during the reporting periods that cover key research areas such as security, political cooperation, Northern Kosovo, ethnic tensions, and violence are analyzed. The transitional process and the mode of transition have been influenced by three important factors that significantly undermined the aim of interim administrators to achieve benchmarks. Moreover, conflicting ethnic interest has emerged as the most influential factor that has had a serious detrimental impact on the mode of transition. The IA has failed to transform individual interests that are still very deeply rooted in the political system and in society. Present diplomatic achievements are still strongly imperiled by a deep bostility in the region, largely because of a chronic ignorance on the part of administrators of the intensity of conflicting ethnic interests. To ensure security in the area an international presence will probably be needed in Kosovo for a very long time.
\end{abstract}

Keywords: UNMIK, conflicting ethnic interests, Resolution 1244, mode of transition, provisional institutions.

\section{Introduction. Research Design and Methodology}

There are several limitations to a conceptual definition and theoretical understanding of the modern concept of IA. These limits are unclear due to a lack of comprehensive studies dealing with the broader metatheoretical impact of the contemporary application of modern IA models on the transformed societies. A vacuum relating to a general understanding of the problem of IA itself complicates further utilization of the model, which is on many occasions influenced by a number of actors and interests. Thus, the impacts of such elements on the whole model tend to spiral. It can run in different and unpredicted directions that can only be correctly measured with difficulty. The structure of the model is therefore affected by particular results of political, strategic and economic concerns that might lead to a hybrid nature of the model and consequently to the model's deformation.

Present understanding of the model of IA and its internal dynamics is still limited. Conventional methods and techniques offer a narrow application. Thus, there is at present no consensus on providing a universal definition for an IA model. This work is based on an empirical and analytical approach to studying mostly primary and then secondary sources. The approach is based fundamentally on qualitative research, the aim of which is to interpret collected information on the one hand and to study the level of regular interactions driving inner deviations inside the IA model applied in Kosovo on the other. The findings were collected by means of several research methods.

\footnotetext{
${ }^{1}$ Contact: Department of International Relations and European Studies, Faculty of Social Studies, Masaryk University,
} Joštova 10, 60200 Brno; e-mail: 366465@mail.muni.cz 
The frontline is covered by a descriptive method. The description is used to interpret the facts that are further combined with an analytical method. The analyses are applied to a deeper examination of the collected data and to studying reciprocity between cause and consequence. Finally, a deductive method is also applied. The purpose of the method is to provide a more comprehensive interpretation of the findings that will be set into a broader framework.

The key aspect of this work is to reach a deeper understanding of the limits of the model as well as to analyze the flows driving resonance inside the model. This paper, together with two previous articles ${ }^{2}$ will form a part of a larger dissertation. The purpose of this work is not to pay general attention to a definition of IA itself or its theoretical constructions, or even to give a general interpretation of phenomena. Rather, the aim of this work is to focus on a study of internal factors and elements that have a crucial impact on the system of acceleration inside the model of transition and the mode of dynamic in the transition. This theoretical framework is subsequently applied to the model of IA in Kosovo. The findings of this work present an important dataset that will serve also for a further work directed towards a final analysis of the effectiveness of the model of IA in Kosovo. ${ }^{3}$

This paper is based on the following hypothetical construction:

An IA in Kosovo neglected the basic determinant of the roots of hostility and partially failed in establishing a suitable definition for the primary conceptual transformation schema. The system ignored a crucial deviational factor inside the model, which resulted in retrogressions of internal transformation flows and contributed to a complicated schema for the consolidation of the country.

The construction is subsequently supported by the following questions.

Could Resolution 1244 itself in some way have been accountable for an internal deviation in the mode of transition and contributed to obstructing the implemented schema?

Were the environment and the strategy of transition able to transform individual interests into a collective identity?

To what extent did the domestic communities in Kosovo modify the unfavorable conditions undermining the mode of the transitional system?

The work is divided into two parts. The first part pays attention to the trajectory accompanying the process of a regime change. The focus is on the study of weak points of the mode of transition in Kosovo. The second part analyzes both the process of interaction and the impact of the international environment and domestic interests in transforming society.

In conducting research for this paper, I relied on four categories of basic source material. Firstly, my analysis focused primarily on the progress reports of the UN SG concerning the transitional administration (TA) mission in Kosovo. The method of analysis rested on process-tracing within this case in order to determine the effect that the interplay between local, national and international

\footnotetext{
${ }^{2}$ The first article "Failing Blueprint? The Indispensable Crossroad of a TA in Kosovo" was published by the Central European Political Studies Review. The article deals with the question of an alternative consolidation for the KosovoSerbia dispute as a result of the collapsing schema of the IA in Kosovo. The following article "Territorial Autonomy: Successful Blueprint for Northern Kosovo?" is currently under external review process for Communist and Postcommunist Studies

${ }^{3}$ It is planned to publish this paper in conjunction with the present article. However, due to time limitations, it can be deemed probable that the findings will be directly integrated into my final thesis without being previously publishing.
} 
factors has had on deviation inside the mode of transition. My second source was the world's most influential newspapers that cover news in a professional way. Thirdly, I analyzed official websites of the government of the Republic of Serbia and the government of the Republic of Kosovo. My study focused primarily on official statements and positions towards particular disputes. The fourth source of information was specialized publications, professional articles and papers. This source provided a particular insight into relevant approaches and views dealing with the problem of transitions and consequently into the modes of implementing strategies.

\section{The Mode of Transition and Conflicting Ethnic Interests}

One of the particular key goals of contemporary international IA missions is the process of state building. "Transitional administration denotes the less common type of operation, in which these ends [quasi-governmental activities such as electoral assistance, assistance with human rights, rule of law technical assistance, security sector reform, and certain forms of development assistance - all directed towards constructing and reconstructing institutions of governance capable of providing citizens with physical and economic security] are pursued by assuming some or all of the powers of the state on a temporary basis" (Chesterman 2005: 5). The complexity of modern TAs can be seen in a number of activities that accompany particular transitions phases. The process of transition from an old regime to a nascent one is followed by a number of decisions and strategies that fully influence the path of the changing political system. Doyle argues that "[E]ffective transitional authority must take into account levels of hostility and factional interests. Whether it in fact does so depends on strategic design and international commitment" (Doyle, Sambanis 2006: 63). A large number of state-building activities force the interim administrators to reform the political system and implement democratic norms and practices into the transforming system. In particular, this pertains to international efforts to develop a democratic regime, one whose rules, procedures and institutions allow for regular and open competition for access to political power, and guarantee the broad range of political and civil liberties that are necessary for such open competition to take place (Tansey 2009: 4).

The process of transition can occur in many ways and in a huge number of possible guises involving similar strategies or political actors. The rationale behind such activities is that establishing zones of stable peace depends not only upon the provision of military security through the wider tasks given to peacekeepers, but also the creation of function liberal polities, economies and societies (Bellamy, Williams, Griffin 2004: 255). It can be progressed by an almost limitless number of trajectories with a different application of transitional strategies. The term transition in democratic regime change has come to denote "an undefined period between the launching of the process of dissolution of an authoritarian regime at the outset and the installation of some form of democracy or the return to some form of authoritarian rule, or the emergence of a revolutionary alternative at the end" (Shain, Linz 1995: 128). A transition process is always quite a big challenge that exercises all parties involved in the process: "Achieving a sustainable peace could broadly be conceived as a triangle, matching the right level and kind of international capacities to the degree of material destruction and to the political hostility that the civil war had wrought" (Doyle, Sambanis 2006: 303). 
The domestic environment always comprises, and international administrators always face a different mix of interests of actors directly or indirectly involved in a transition. The mode of transition is fully conditioned by a number of variables deeply rooted in both domestic and international environments.

\section{Case Application - One}

The UNMIK is a multi-structured mission of the UN. In spite of its complexity, the transition process in Kosovo has uncovered some fluctuations that have a quite radical impact on the mode of transition itself. In some ways, the international community has overlooked an important factor that has had a seriously detrimental effect on the implemented strategies. The existence of strengthening and conflicting ethnic interests has been continuously ignored despite a large amount of evidence indicating some resonance in the mode of transition. The strategy of the international community regarding the mode of transition in Kosovo has been based on a belief that an application of democratic principles can resolve the roots of the conflict and eventually lead to local ownership. It was believed that a system based on quotas for both parties - Kosovo Serbs and Albanians - and their participations in the newly-created institutions for provisional governance would diminish tensions inside the society. Moreover, the interim administrators were persuaded that incorporating norms of good governance would allow reconciliation and the future coexistence of the majority and the minority.

On the contrary, conflicting ethnic interests have continuously undermined the situation and contributed to serious complications with respect to achieving benchmarks. The lack of a clear strategy dealing with this problem consequently led to the limited participation of members from both ethnic communities in the newly-created institutions for provisional self-governance. Moreover, the resulting vacuum further intensified violence in the society. The term conflicting ethnic interests in Kosovo demonstrates a quite interesting paradox. It is related to a different perception of the future coexistence of Kosovo Serbs and Albanians side by side in the territory. Both parties, in fact, strive towards dominance; historically, there have been initiatives on both sides since the fall of the Ottoman Empire to establish their particular dominance in the region. (Jureković 2006: 79-131). The society continuously exhibits a tendency within which both ethnic communities still have, in their eyes, legitimate reasons for continuing to struggle for supremacy. In 2005, Kai Eide reported slight progress in this area and the importance of intensifying the application of security standards in accordance with UN Resolution 1244 request for a multi-ethnic society. Regrettably, however, little has been achieved to create the foundation for a multi-ethnic society. As the UN report states, the Kosovo leaders and the international community should take urgent steps to correct this grim picture (S/2005/635, 2005: para. 44). The Progress Reports of the UN SG on UNMIK clearly indicate that in spite of the international presence and its keen efforts, conflicting ethnic interests have persisted. The situation concerning the existence of different individual interests was worsened by the announcement of the unilateral Declaration of Independence and recently by the adoption of the EU-brokered landmark accord. Since the Declaration of Independence, participation of the minority in public affairs has diminished: "Kosovo Serbs with the support of the Serbian authorities 
have expanded their boycott of the institutions of Kosovo (...) This expanded boycott has not been uniform, however. Although Kosovo Serb civil servants have stopped coming to work in municipalities where they make up either a majority, or a significant proportion, of the population (...) they have continued to work in municipalities where they remain a small minority (...) At the central level, leaders of Kosovo Serb political parties have continued to have informal contacts with UNMIK and the Government of Kosovo" (S/2008/211, 2008: para. 8).

The continuing existence of parallel administrative structures has presented another problem. Parallel structures were reported at the national level as well as at the level of municipalities principally in the areas of education, health and administrative services (S/2002/1126, 2002: para.7). The plurality of society has presented a very important complication with respect to integrating all members of communities into one social identity. During the IA, international actors have extended their efforts to change the political dynamics to provide an incentive to dismantle parallel structures and to encourage all communities to participate in join institutions (S/2002/1126, 2002: para. 8).

There has been continuous discrimination against ethnic groups in Kosovo, predominantly against the Kosovo Serbs and Roma with regard to employment opportunities in the private sector. The issue of property has become a major concern. Language policy has still not reached the set standards. Kosovo institutions have had a problem in finding the required number of language interpreters to ensure equal access for all members of the community to public services (S/2006/707, 2006: Annex 1). The discrimination against ethnic groups persists deeply in the society and incidences of it can be observed in both directions - intraethnic and interethnic. Serious human rights violations have been regularly reported during the presence of the IA in Kosovo. Most of the violations are based on ethnicity. Kosovo Serbs, Roma and Slavic Muslims ${ }^{4}$ are the most common targets. The violence occurred mostly in the few areas of Kosovo where minority ethnic groups and Kosovo Albanians live close to each other (S/2000/177, 2000: para. 49). The March 2004 violence occurred in the ethnically divided Mitrovica region of northern Kosovo, whereby a total of 19 persons died, of whom 11 were Kosovo Albanians and 8 were Kosovo Serbs, and 954 persons were injured in the course of the clashes. "Approximately 730 houses belonging to minorities, mostly Kosovo Serbs, were damaged or destroyed. In attacks on the cultural and religious heritage of Kosovo, 36 Orthodox churches, monasteries and other religious and cultural sites were damaged or destroyed" (S/2004/348, 2004: para. 3). Inter-ethnic tensions remain quite serious questions and complicate peaceful development mostly in the area along the Ibër/Ibar River, where the situation remains fragile and both the Kosovo Serbian and Kosovo Albanian communities react instantly to what they consider a provocation by the other community (S/2011/43, 2011: para. 22). In recent decades, ethnic tensions have erupted not only into violent clashes between members of communities, but also into violence aimed at the international presence in the area (S/2012/72, 2012: para. 3 - para. 16).

\section{The Mode of Transition - Domestic and International Conditions}

\footnotetext{
${ }^{4}$ This group is officially called Bosniaks in Kosovo
} 
As Doyle and Sambanis put it, "[E]ffective transitional authority that governs how peacekeeping, peace-building and peace enforcement are exercised must be designed to fit the case if it is going to succeed in establishing a self-sustaining peace" (Doyle, Sambanis 2006: 321). The mode of transition is generally understood as the most important element of transition. It carries both dependent and independent variables that define the whole process of transition. The mode determines and modulates the schema for the whole interaction between international actors and their domestic counterparts: "The interim government usually operates within a context of volatility and political vulnerability marked by uncertainty, anxiety and high expectations concerning the future distribution of power and loyalties" (Shain, Linz 1995: 128).

The mode of transition has some remarkable limitations. The problem could be found in its limited focus on variables influencing the process of transition in a particular territory. It pays too much attention to explaining how domestic variables influence the process of transition. However, it is very reluctant to explain the influence of international actors on the process. Tansey in his book Regime-Building: Democratization and Interim Administration argues that the contemporary mode of transition needs to be revised to incorporate the important influence of the international and domestic context and internal and external fluctuations (Tansey 2009: 4). In this respect, international actors are a part of the transitional governance and thus they are directly involved in the central processes of regime change. External elites explicitly promote the development of democratic regimes, interact with local actors, and often play roles that in more conventional cases are associated with domestic actors (Tansey 2009: 4).

The cooperation between all the parties taking part in the transitional process and the resulting international influence on the transition is not a one-way process. Each of the actors in transition plays a different role. Their behavior is therefore conditioned by their origin, their history, and even their different accountabilities to individual parties. International administrators are fully subordinated and obligated to international bodies, while domestic elites have to meet the expectations of the local population. Furthermore, each of these parties in question shares responsibility for the consequences. It is not possible for only one party in this relationship to bear all the responsibility and to accept all the blame for any negative outcomes.

The IA possesses a high level of power. The process itself is composed of a number of activities that significantly change political and social conditions in a transitional territory. The impact of the IAs on local elites and political structures can be visible in the ability of the IA to affect a trajectory over the social development and social behavior of all influential elites. The IA is entitled by its extensive power. Once the transitional mechanism is implemented, the system of transition has full control over domestic elites and actors, and can take primary control of the whole of the development and the implementation of political wishes.

The influence of an IA is not necessarily positive. The implementation of democratic principles can also lead to deadlock in the transition process. Another example concerns international administrators as personnel from different international organizations. Their different origins, traditions and values can add tensions to the process. In some cases, these may undermine the achievement of standards, the setting of goals, and even the reaching of particular stages in the process of transition. International administrators cannot, without close cooperation with domestic 
elites, guarantee the problem-free transformation of a region to a fully democratic political state. Even after the withdrawal of the international presence, there is still a significant degree of danger. The territory can return to its authoritarian past or adopt a form of hybrid regime where the institutions of democracy are shown to co-exist with non-democratic behaviour, resulting in a form of "competitive authoritarianism" that has more in common with authoritarian than democratic rule (González F.E., King D. 2004: 193-210).

\section{Case Application - Two}

Kosovo provides an explanatory example of an extremely divided society within which it is almost impossible to create a collective identity. The mode of transition in Kosovo has been particularly influenced by a triumvirate of main actors involved in the process. This triangulation has driven very-difficult-to-control flows inside the model of IA in Kosovo, which has simultaneously led to numerous deviations inside the internal flows of the schema. As has already been argued, these inconsistencies in the mode of transition have not only arisen because of conflicting ethnic interests.

The question of Kosovo's final status was the second driving force creating such deviations. The transitional period is full of various events that reflect a distance between the domestic elites and international administrators. The basic strategy of the international community in respect to Kosovo was to implement a system of affirmative action related to a system of representative participation. It seems quite ironic that the system was criticized by a high representative ${ }^{5}$ who noted that the recruitment of minorities has too often been seen as a question of filling a quota rather than one of providing meaningful participation (S/2005/635, 2005: para. 22). The system represents a quasi-hybrid system that proposes a combination of proportional representation with a system of reserved positions. Such a system relates to the problem of conflicting ethnic interests, which was analyzed in the previous case application. In Kosovo, this system was implemented in many segments, which included provisional institutions for self-government as well as those relating to employment. This strategy, however, accentuated a deep divergence between domestic elites on one side and between domestic elites and international community on the other one.

The problem of the Kosovo Serbs is closely connected to Belgrade's position. On the one hand, representatives of the Kosovo Serb community have constantly undermined the IA structure and looked for support from Belgrade. On the other, Albanian leaders have followed and supported the strategy of the IA mission. Belgrade has always been perceived as a third element in the mode of transition that has played a very important role. Despite Belgrade's official support for action and policies of Interim administrators, it also provided assistance to the parallel structure (S/2006/361, 2006: Annex 1, para. 8) in Northern Kosovo. Belgrade was quite unclear about its true position and sent numerous mixed signals to Serbian representatives and the Serbian minority with respect to participation in elections (S/2004/907, 2004: Annex 1) and the Kosovo Serb presence in the provisional governmental structures created by UNMIK in Kosovo.

\footnotetext{
${ }^{5}$ Kai Eide - the Special Envoy to the UN Secretary General
} 
However, the poor participation of local personnel in transitional institutions could be observed on both sides, which minimized the prospect of a successful transition. The Serbian influence on Kosovo Serbs increased continually. The boycott of Kosovo Serbs and their minimal participation in transitional institutions could be credited to their loyalty to Belgrade as well as to fears that the quick achievement of benchmarks would accelerate the process towards a final status for Kosovo which they would find unfavorable. The UN reported that with regard to the implementation of standards very little was achieved. In spite of a new institutional political framework being established, the system was still influenced by political interests and ethnic identity (S/2005/635, 2005). On the other hand, Kosovo Albanians decreased their participation in the transitional institutions and in the election system mostly because of uncertanty and an unclear strategy relating to the final status of the region.

The third element driving deviation inside the mode of transition can be credited to the formulation of Resolution 1244 itself. The vagueness of UN Resolution 1244 provided for no concrete final settlement with respect to Kosovo's status. UN Resolution 1244 invested the IA with the power to provide the people of Kosovo with substantial autonomy (S/RES/1244, 1999: para.10). The IA was deployed to establish and oversee the development of provisional democratic self-governing institutions which would ensure conditions for a peaceful and normal life for all inhabitants of Kosovo (S/RES/1244, 1999: para. 10). The situation in 2007 and 2008 provided an example of deviational turmoil inside the mode of transition that has its roots in the basic document of the mission. The existence of an unclear strategy relating to the final status of Kosovo intensified the tensions between domestic elites, which were further transformed into escalating ethnic violence in the streets.

The situation became more complicated after the Contact Group was brought into being. The Contact Group was divided about the question of the final status of Kosovo, Russia supporting Belgrade's view and the US and Great Britain supporting independence for Kosovo. In 2007, a UN report recommended that Kosovo should become an independent state with supervision under the auspices of the international community (S/2007/168, 2007). The report described Kosovo as a limbo state that could not continue under the defined strategy: "[D]enying or delaying a resolution to the issue of Kosovo's status risked challenging not only its own stability but the peace and stability of the region as a whole" (S/2007/168, 2007: para. 4). The proposal was, however, rejected by the Republic of Serbia. In reaction to the proposed plan, the National Assembly of the Republic of Serbia adopted a resolution (Serbian Government 2007a) declaring Kosovo-Metohija ${ }^{6}$ an integral part of the territory of Serbia. The UN proposal that Kosovo should become an independent state was rejected as unlawful and illegitimate (Serbian Government 2007b).

The following Declaration of Independence created another disturbance in the mode of transition and further polarized the communities. Serbia viewed the declaration as a unilateral intention to secede by force from the territory of Serbia, which did not have any legal status either in Serbia or in the international legal order: "The Kosovo Serbs (...) held daily, largely peaceful protests in several areas in Kosovo where Kosovo Serbs lived, including northern Mitrovicë/Mitrovica,

\footnotetext{
${ }^{6}$ the term is used by the Republic of Serbia for Kosovo.
} 
Graçanicë/Gračanica, Kamenicë/Kamenica and Shtërpcë/Štrpce” (S/2008/211, 2008: para. 6-7). The transformation of competencies from the UNMIK in Kosovo to EULEX in accordance with the transformation strategy was obstructed by Belgrade. Belgrade stated that Serbia would never recognise Kosovo's independence nor the presence of EULEX unless they had received prior UN Security Council approval (Serbian Government 2008).

After diplomatic talks brokered by the EU, Pristine and Belgrade showed a willingness to normalize their relations. Since then, there has been a great deal of diplomatic pressure on both sides and a new shift can be observed in recent diplomatic achievements such as common agreement on numerous sensitive issues (S/2012/603, 2012: para. 14) ${ }^{7}$ and a few positive steps towards the implementation of agreements on regional cooperation and the joint management of crossing points (S/2012/818, 2012: para. 18).

\section{Conclusion}

As has been shown, conflicting ethnic interests have quite deep roots in Kosovo society and have manifested a tendency to increase since the arrival of the international presence in the area. Were the conditions and strategy of the transition able to transform individual interests into a collective identity? As has been indicated, conflicting ethnic interests present a significant variable in Kosovo and still present a very serious impediment to future development in the wake of the EUbrokered landmark accord. Causality can be observed in the flows running inside the mode of transition, where intense conflicts of ethnic interest have a direct negative impact on local participation with a resulting influence on the mode of transition. Indisputably, the strategy of transformation covers a large number of possible alternatives; however, the dynamic inside the mode of transition demonstrated that conflicting ethnic interests limited local participation and that the vacuum surrounding the final status of Kosovo accelerated a dynamic process leading to negative consequences. It has been indicated that the mode of transition based on western democratic principles has had a minimal effect on the creation of a collective identity and that conflicting ethnic interests are still very much in evidence. This lack of real effectiveness on the part of the IA has been a catalyst for other factors ${ }^{8}$ that have complicated the implementation of strategies and made the defined standards more difficult to achieve.

It has been shown that the interim administrators have partially failed in their aim to transform individual interests into a collective identity. Kosovo Serbs still perceive themselves to be an inherent part of the Republic of Serbia and refuse to incorporate themselves into Kosovo society, strongly rejecting the institutions of the Republic of Kosovo (S/2012/818, 2012: para. 8). This dynamics has led to a vicious circle within which each element influences the others and each element has a direct impact on the others. Moreover, institutions of the transitional structure were not fully able to resolve the competition between ethnic identities. Conflicting ethnic interests have become a part of

\footnotetext{
${ }^{7}$ For details see $\mathbf{S} / \mathbf{2 0 1 2 / 6 0 3}$, para. 14 - a list of important agreement areas.

8 This paper is strictly narrowed to analyze three elements influencing the mode of transition itself. This paper does not pay any attention to due to limited space. The broader analysis is a part of the dissertation.
} 
day-to-day life and are deeply institutionalized in the present system. They still represent a very important factor that has contributed to deviations inside the mode of transition and the anomalies in international structures, institutions and transitional structures in Kosovo. Recent talks between Belgrade and Pristine under the auspices of the UN and the EU indicate the continuing divisions inside Kosovo society. The talks were accompanied by a number of incidents and tensions on the ground (S/2013/72, 2013: para. 9).

Could Resolution 1244 itself be in some way accountable for internal deviations in the mode of transition and have contributed to the obstruction of the implemented schema? The transitional system was continuously exposed to a keen criticisms pointing at the need to build a stronger socio-political responsibility and higher "participatory approaches" throughout effective local institutions that should not have been a "substitute for top-down decision-making by international missions" (Narten 2006: 159). The deteriorating situation during the whole transitional process demonstrates that the escalation of ethnic conflicts and tensions was in direct relation to the insecurity and uncertainty with regard to the future development and final status of Kosovo. It is argued that the lack of clarity of Resolution 1244 concerning Kosovo's final status could be a partial reason for the strong tensions and fluctuations in the mode of transition. The uncertainty with regard to the future status of Kosovo was a very important factor that undermined the achievement of local ownership, for it is impossible to own something the nature of which one cannot imagine or comprehend beforehand (Knoll 2005: 637-660). The different interests of the Great powers during the formulation of Resolution 1244 together with a lack of strong action, the absence of a clear mandate and the open question of Kosovo's final status deeply anchored conflicting ethnic interests into Kosovo society. This consequently jeopardized subsequent strategies for creating the institutions of self-government in Kosovo. Moreover, the vagueness of Resolution 1244 about Kosovo's final status opened up a space for very dangerous maneuvers and obstructions on the part of Belgrade, which has made the process of transition, in some phases, quite complicated.

To what extent did the domestic communities in Kosovo modify the unfavorable conditions undermining the mode of the transitional system? During the whole process of transition, the IA was faced with one of the most polarized societies in the world. The lack of a collective identity has very deeply polarized the members of all communities and has complicated the achievement of benchmarks. The polarization inside Kosovo's society has been strengthened by very strong conflicting ethnic interests, which in the end have contributed to the confounding behavior of all communities. The polarization and the deterioration in the mode of transition have to be viewed from a broader perspective and are closely related to conflicting ethnic interests. The influence of one group has an inevitable impact on the behavior of the other group and the behavior of international actors. Belgrade has always played a much too important role in forming public opinion among Kosovo Serbs and influencing the behavior of the key elite members of the community. The limited mandate and weak structural competencies of the UNMIK in Kosovo enable Belgrade, in many situations, to influence the trajectory of the settlement. The strong divisions driving disputes between key members of community elites has limited the transformation of the society and the participation of community members in provisional institutions in Kosovo. It is manifest that the society in Kosovo is still strongly divided in spite of the clear aims of the 
transitional authority. Moreover, the situation after the Declaration of Independence significantly contributed to strong political tensions in Northern Kosovo (S/2010/562, 2010: para. 17). As has been demonstrated, a missing collective identity has, in many cases, been a cause of escalating violence, serious ethnic clashes, and security fears (S/2012/818, 2012: para. 23).

This study has shown that the UNMIK and the mode of transition itself have been continuously undermined by key phenomena that are still very deeply rooted in Kosovo society. This work argues that despite the approaching end to supervised independence (S/2012/603, 2012: para. 7), conflicting ethnic interests ${ }^{9}$ still present a serious issue with respect to future development in Kosovo. The recent EU-brokered landmark accord indicates a shift in understanding. It is very probable that a revised perception of the future coexistence of ethnic communities in Kosovo and the serious problem of a lack of collective identity among these communities will force the international community to maintain its deployment in the area for a very long time to come.

\section{List of Abbreviations}

$\begin{array}{ll}\text { IA } & \text { Interim Administration } \\ \text { SG } & \text { the Secretary General } \\ \text { SC } & \text { the Security Council } \\ \text { UNMIK } & \text { the United Nations Interim Administration Mission in Kosovo } \\ \text { UN } & \text { the United Nations } \\ \text { TA } & \text { Transitional Administration }\end{array}$

\section{Bibliography}

All on-line sources cited as to 1 May 2013.

Bellamy J.A., Williams P., Griffin S. (2004).Understanding Peacekeeping, Cambridge: Polity Press

Chesterman, Simon. (2005). You, the People: The United Nations, Transitional Administration, and StateBuilding (Project of the International Peace Academy), New York: Oxford University Press

Doyle, Michael a Sambanis, Nick (2006). Making War and Building Peace: United Nations Peace Operations.

New Jersey: Princeton University Press.

González, Francisco E. a King, Desmond (2004). The State and Democratization: The United States in Comparative Perspective, British Journal of Political Science, Vol. 34, No. 2, 193-210. DOI: 10.1017/S0007123404000018

Jureković, Predrag (2006). Internationales Konfliktmanagement im Fokus: Kosovo, Moldova und Afghanistan im kritischen Vergleich, Baden-Baden: Nomos

Knoll, Bernhard (2005). From Benchmarking to Final Status? Kosovo and the Problem of an International Administration's Open-Ended Mandate, European Journal of International Law Vol. 16, No. 4, 637-660. DOI: $10.1093 /$ ejil/chi140

Narten, Jens (2006). Building local institutions and parliamentarism in post-war Kosovo a review of joint efforts by the UN and OSCE from 1999-2006, Helsinki monitor Vol. 17, No. 2, 144-159

\footnotetext{
9 The problem of the conflict ethnic interests and their impact on both the future development and diplomatic activities will be elaborated in a separate section of my dissertation.
} 
S/2000/177, 2000. Report of the Secretary General on the UNMIK in Kosovo, The UN Security Council, on-line (http://www.unmikonline.org/SGReports/S-2000-177.pdf)

S/2002/1126, 2002. Report of the Secretary General on the UNMIK in Kosovo, The UN Security Council, on-line (http://www.unmikonline.org/SGReports/S-2002-1126.pdf)

S/2004/348, 2004. Report of the Secretary General on the UNMIK in Kosovo, The UN Security Council, on-line (http://www.unmikonline.org/SGReports/S-2004-348.pdf)

S/2004/907, 2004. Report of the Secretary General on the UNMIK in Kosovo, The UN Security Council, on-line (http://www.unmikonline.org/SGReports/S-2004-907.pdf)

S/2005/635, 2005. Report of the Secretary General on the UNMIK in Kosovo, The UN Security Council, on-line (http://daccess-dds-

ny.un.org/doc/UNDOC/GEN/N05/540/69/PDF/N0554069.pdf?OpenElement)

S/2006/361, 2006. Report of the Secretary General on the UNMIK in Kosovo, The UN Security Council, on-line ( http://www.unmikonline.org/SGReports/S-2006-361.pdf)

S/2006/707, 2006, Report of the Secretary General on the UNMIK in Kosovo, The UN Security Council, on-line (http://www.unmikonline.org/SGReports/S-2007-707.pdf)

S/2007/168, 2007. Report of the Secretary General on the UNMIK in Kosovo, The UN Security Council, on-line (http://daccess-dds-

ny.un.org/doc/UNDOC/GEN/N07/272/23/PDF/N0727223.pdf?OpenElement

S/2008/211, 2008. Report of the Secretary General on the UNMIK in Kosovo, The UN Security Council, on-line (http://www.unmikonline.org/SGReports/S-2008-211.pdf)

S/2010/562, 2010. Report of the Secretary General on the UNMIK in Kosovo, The UN Security Council, on-line (http://www.unmikonline.org/SGReports/S-2010-562.pdf)

S/2011/43, 2011. Report of the Secretary General on the UNMIK in Kosovo, The UN Security Council, online (http://www.unmikonline.org/SGReports/S-2011-43.pdf)

S/2012/603, 2012. Report of the Secretary General on the UNMIK in Kosovo, The UN Security Council, on-line (http://www.unmikonline.org/SGReports/S-2012-603.pdf)

S/2012/72, 2012. Report of the Secretary General on the UNMIK in Kosovo, The UN Security Council, online (http://www.unmikonline.org/SGReports/S-2012-72.pdf)

S/2012/818, 2012. Report of the Secretary General on the UNMIK in Kosovo, The UN Security Council, on-line (http://www.unmikonline.org/SGReports/S-2012-818.pdf)

S/2012/818, 2012. Report of the Secretary General on the UNMIK in Kosovo, The UN Security Council, on-line (http://www.unmikonline.org/SGReports/S-2012-275.pdf)

S/2013/72, 2013. Report of the Secretary General on the UNMIK in Kosovo, The UN Security Council, online (http://www.unmikonline.org/SGReports/N1321969.pdf)

S/RES/1244, 1999. The United Nations Security Council online, on-line (http://www.un.org/ga/search/view_doc.asp?symbol=S/RES/1244)

Serbian Government (2007a). Resolution following UN Special Envoy Martti Abtisaari's "Comprehensive Proposal for the Kosovo Status Settlement" and continuation of negotiations on the future status of Kosovo-Metobija, on-line (http://www.srbija.gov.rs/kosovo-metohija/index.php?id=31735)

Serbian Government (2007b). Serbia rejects Abtisaari's proposal before UN Security Council and requests new international mediator, on-line (http://www.srbija.gov.rs/vesti/vest.php?id=32983) 
Serbian Government (2008). Serbia will not accept EULEX without UN Security Council approval, on-line (http://www.srbija.gov.rs/vesti/vest.php?id=48035)

Shain, Yossi a Linz, Juan J. (1995). Between States: Interim Governments and Democratic Transitions. Cambridge: Cambridge University Press

Tansey, Oisín (2009). Regime-Building: Democratization and International Administration, New York: Oxford University Press 